TITLE:

\title{
Construction of the ACDE Ring System of Calyciphylline A-type Alkaloids via Intramolecular Diels- Alder Reaction of a Tetrasubstituted Olefin
}

\section{$\operatorname{AUTHOR}(S):$}

Nakamura, Hugh; Kawakami, Manami; Tsukano, Chihiro; Takemoto, Yoshiji

\section{CITATION:}

Nakamura, Hugh ...[et al]. Construction of the ACDE Ring System of Calyciphylline A-type Alkaloids via Intramolecular Diels-Alder Reaction of a Tetrasubstituted Olefin. Synlett 2019, 30: 2253-2257

\section{ISSUE DATE:}

2019-01-01

\section{URL:}

http://hdl.handle.net/2433/246188

\section{RIGHT:}

This is the accepted manuscript of the article, which has been published at https://doi.org/10.1055/s-0039-1690267. The full-text file will be made open to the public on 7 November 2020 in accordance with publisher's 'Terms and Conditions for Self-Archiving':; This is not the published version. Please cite only the published version.; この論文は出版 社版でありません。引用の際には出版社版をご確認ご利用ください。 


\section{Construction of the ACDE Ring System of Calyciphylline A-type Alkaloids via Intramolecular Diels-Alder Reaction of a Tetra-substituted Olefin}

\author{
Hugh Nakamuraa \\ Manami Kawakamia, \\ Chihiro Tsukano*a \\ Yoshiji Takemoto*a \\ ${ }^{a}$ Graduate School of Pharmaceutical Sciences, Kyoto \\ University, Yoshida, Sakyo-ku, Kyoto, 606-8501, Japan. \\ *Corresponding authors: tsukano@pharm.kyoto- \\ u.ac.jp,takemoto@pharm.kyoto-u.ac.jp
}

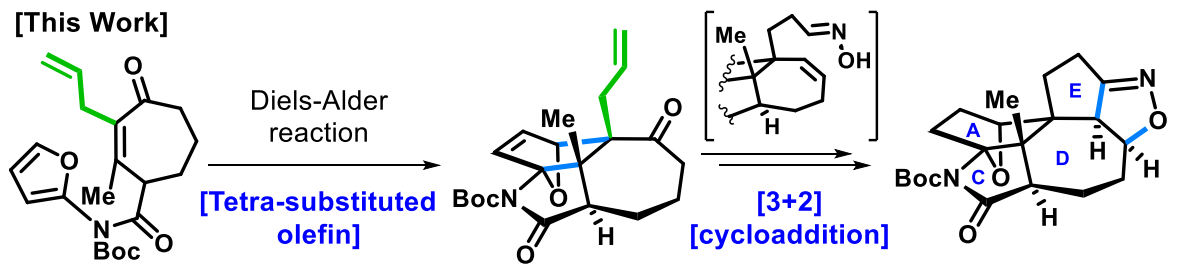

Abstract A concise synthesis of the ACDE tetracyclic ring system of calyciphylline A-type alkaloids was investigated. The intramolecular DielsAlder reaction of a tetra-substituted olefin with furan enabled the construction of the $A C D$ ring system bearing two contiguous quaternary carbons in one step, and subsequent intramolecular [3+2] cycloaddition successfully gave the $\mathrm{E}$ ring.

Keywords Daphniphyllum alkaloid, Calyciphylline A, Diels-Alder reaction, tetra-substituted olefin

Calyciphylline A-type alkaloids, which include daphniyunnines, daphnipaxianines, daphnilogeranines, and daphniglaucins, are a subfamily of Daphniphyllum alkaloids and feature a complex hexacyclic core framework and two contiguous quaternary carbon centers (Figure 1). ${ }^{1}$ To date, over 320 Daphniphyllum alkaloids, including over 35 calyciphylline A-type alkaloids, have been isolated from the Daphniphyllum genus. ${ }^{2}$ These Daphniphyllum alkaloids have been reported to exhibit fascinating bioactivity, including anticancer, anti-HIV, and anti-oxidant activity. The unique skeleton and promising bioactivity of calyciphylline A-type alkaloids have attracted the interest of synthetic chemists for decades, ${ }^{3-5}$ culminating in elegant total syntheses of longeracinphyllin $A,{ }^{6}$ daphnilongeranin $B, 7$ daphnipaxianine $A,{ }^{8}$ himalensine $D,{ }^{9}$ and hybridaphniphylline. ${ }^{10}$ Recently, we have also reported the concise construction of the ACDE ring system of calyciphylline A-type alkaloids having contiguous quaternary centers by a [5+2] cycloaddition of oxidopyrylium species. ${ }^{11}$ To provide various analogs, it is desirable to develop an alternative synthetic route to the core structure, enabling core structures having different functionalities. In this paper, we report a concise route to the ACDE skeleton bearing two contiguous quaternary carbon centers, using an intramolecular Diels-Alder reaction of a tetra-substituted olefin.

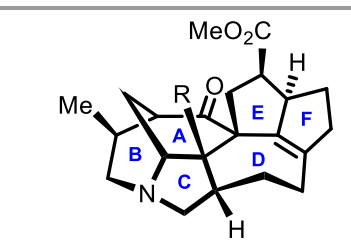

daphniyunnine $A(R=M e)$ $\begin{array}{ll}\text { daphniglaucin } D\left(R=\mathrm{CH}_{2} \mathrm{OH}\right) & \text { daphniyunnine } \mathrm{D}(\mathrm{R}=\alpha-\mathrm{OH}) \\ \text { calyciphylline } \mathrm{A}(\mathrm{R}=\mathrm{Me}, \mathrm{N} \text {-oxide }) & \text { daphniyunnine } \mathrm{E}(\mathrm{R}=\beta-\mathrm{OH})\end{array}$

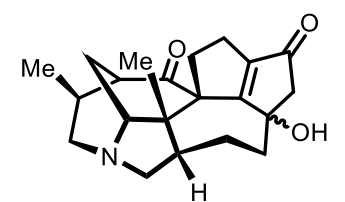

daphnipaxianine $\mathrm{A}(\alpha-\mathrm{OH})$ daphnipaxianine $\mathrm{B}(\beta-\mathrm{OH})$

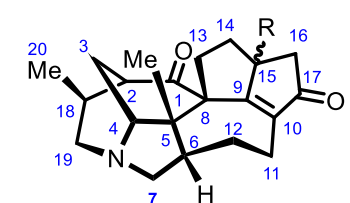

daphnilongeranin $B(R=\alpha-H)(1)$ daphniyunnine $\mathrm{D}(\mathrm{R}=\alpha-\mathrm{OH})$

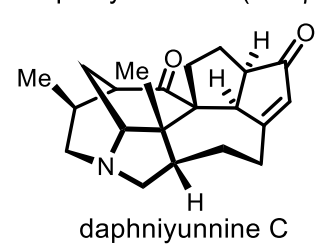

Figure 1 Structures of Calyciphylline A-type Alkaloids.

One of the challenges in the synthesis of calyciphylline Atype alkaloids is the stereoselective construction of the ACD ring core bearing contiguous C5 and C8 quaternary carbons. While this congested structure can be robustly constructed by stepwise routes, it is difficult to construct in one step. ${ }^{11}$ In 2017 , Dixon and co-workers achieved the total synthesis of himalensine A via an intramolecular Diels-Alder reaction using a novel organocatalyst, which contained a bifunctional iminophosphorane, to construct the ACD core in a diastereoand enantio-selective manner (Scheme 1a). ${ }^{9}$ If this Diels-Alder reaction could be extended to a tetra-substituted olefin, ${ }^{12}$ the ACD ring core bearing contiguous quaternary carbons could be readily accessed. To explore this possibility, we investigated the synthesis of the ACDE ring skeleton $\mathbf{4}$ bearing two quaternary carbons as a key intermediate (Scheme $1 \mathrm{~b}$ ). The F ring, which is responsible for the diversity of various calyciphylline A-type alkaloids, can then be derivatized from the isooxazoline of the intermediate $\mathbf{4}$, along with the formation of the $\mathrm{B}$ ring via a vinyl enolate coupling according to Bonjoch's report. ${ }^{4 a}$ The $\mathrm{E}$ ring of intermediate 4 can be constructed by intramolecular [3+2] cycloaddition ${ }^{5 \mathrm{~d}}$ of compound 5, which can be synthesized from compound $\mathbf{6}$. We envisioned that the intramolecular Diels-Alder reaction of a tetra-substituted olefin linked with furan, compound $\mathbf{7}$, prepared from the known compound $\mathbf{8}$, would provide the 
intermediate 6. This route requires not only development of optimized reaction conditions, but also identification of a suitable linker for the intramolecular Diels-Alder reaction of compound $\mathbf{7}$.

a) Dixon's Work

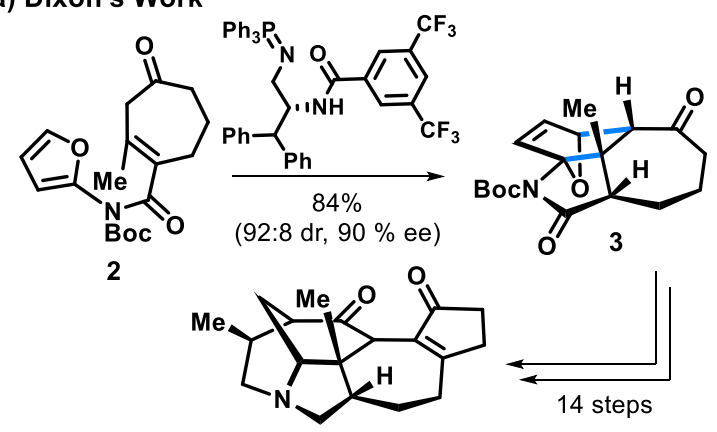

$(-)$-himalensine A

\section{b) This Work}

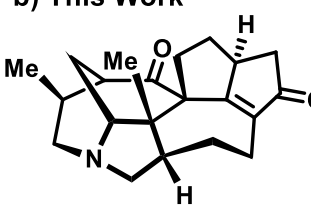

daphnilongeranin B (1)

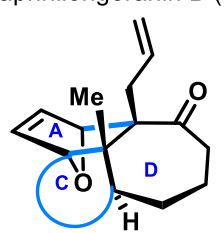

$6 \rrbracket \begin{gathered}{[\text { Diels-Alder }} \\ \text { Reaction }]\end{gathered}$

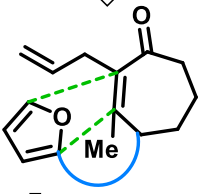

7

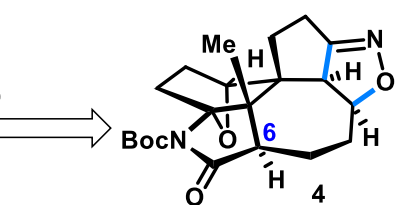

$[3+2$

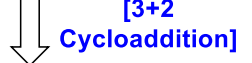

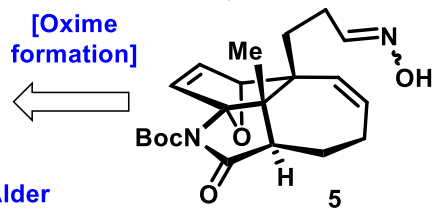

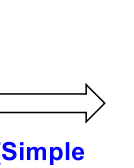

buildng block]

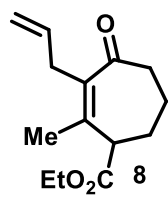

Scheme 1 Retrosynthetic Analysis of Calyciphylline A-type Alkaloids.

For the initial examination of the intramolecular DielsAlder reaction, substrates $\mathbf{7 a}, \mathbf{7 b}$, and $\mathbf{7 c}$ were synthesized from the known compound $\mathbf{8}$, which was readily prepared from commercially available ethyl 2-oxocyclopentanecarboxylate and methyl tetrolate by Dixon's procedure (Scheme 2). ${ }^{13}$ DIBAL-H reduction of compound 8 was followed by $\mathrm{MnO}_{2}$ oxidation of the resultant allyl alcohol to give enone $\mathbf{9}$, which was coupled with 2-furoic acid to form compound $\mathbf{7 a}$. Compound 8 was also derivatized into compound $\mathbf{7 b}$, through hydrolysis to form carboxylic acid $\mathbf{1 0}$ and coupling with 2furfuryl alcohol. Carboxylic acid $\mathbf{1 0}$ was treated with pivaloyl chloride and $\mathrm{N}$-methyl morpholine, then deprotonated tertbutyl furan-2-ylcarbamate, ${ }^{14}$ to afford amide $\mathbf{7 c}$ in $82 \%$ yield via a mixed anhydride in situ.

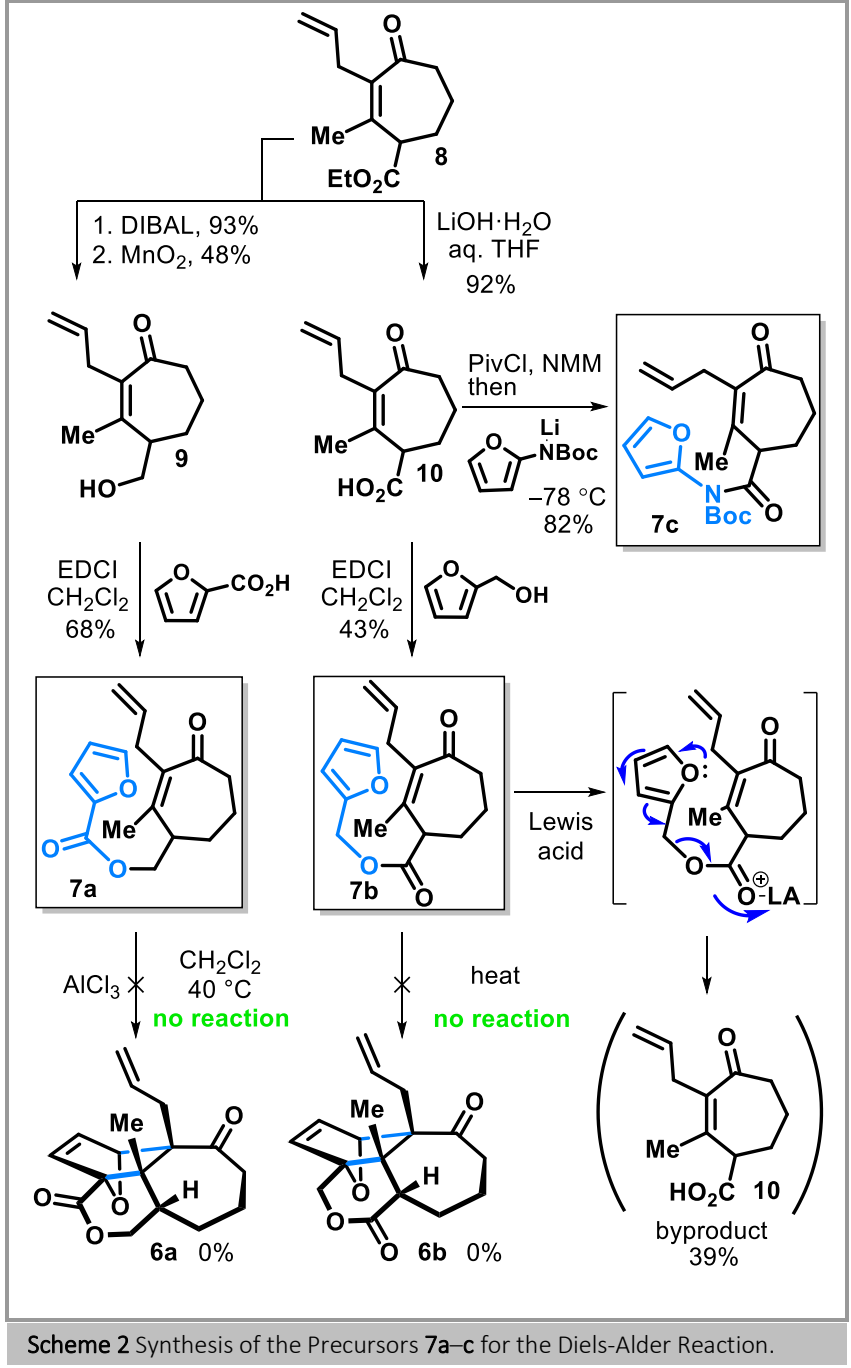

With the cyclization precursors $\mathbf{7 a - c}$ in hand, we next attempted the construction of the $\mathrm{A}$ and $\mathrm{C}$ rings of calyciphylline A-type alkaloids by an intramolecular DielsAlder reaction. While compound $\mathbf{7 a}$ was treated with $\mathrm{AlCl}_{3}$ in $\mathrm{CH}_{2} \mathrm{Cl}_{2}$ at room temperature and $40{ }^{\circ} \mathrm{C}$, the reaction did not proceed at all, probably due to the low electron density of the diene moiety (Scheme 2). Additionally, the reaction of $\mathbf{7 b}$ under thermodynamic or Lewis acidic conditions did not give the desired product $\mathbf{6 b}$ due to elimination of an carboxylate to give byproduct 10 . On the other hand, when $\mathbf{7 c}$ was treated in toluene at $110{ }^{\circ} \mathrm{C}$, the cyclized products $\mathbf{6 c}$ and $\mathbf{1 1}$ were obtained in $6 \%$ and $72 \%$ yields, respectively (Table 1 , entry 1 ). The relative stereochemistry of these two compounds was determined by X-ray crystallography (Scheme 3). Unfortunately, the major product 11, which was a thermodynamic product, ${ }^{15}$ was revealed not to have the required stereochemistry at $\mathrm{C} 6$. To invert the selectivity of this Diels-Alder reaction, we next investigated various Lewis acids, expecting that the coordination of Lewis acids to the carbonyl group and tert-butoxycarbonyl (Boc) group on the $\mathrm{C}$ ring would affect the conformation of the transition state of the Diels-Alder reaction. However, the use of $\mathrm{Mg}\left(\mathrm{ClO}_{4}\right)_{2}, \mathrm{Yb}(\mathrm{OTf})_{3}$, or $\mathrm{Ti}(\mathrm{OiPr})_{4}$ resulted in removal of the Boc group to give only product 12 (entries 2-4). On the other hand, the use of $\mathrm{Cu}(\mathrm{OTf})_{2}, \quad \mathrm{BF}_{3} \cdot \mathrm{Et}_{2} \mathrm{O}, \quad$ or TMSOTf afforded the desired stereoisomer $\mathbf{6 c}$ with excellent selectivity, albeit in low yield 
(entries 5-7). We suspected that these low yields might be because of the decomposition of compound $\mathbf{6 c}$ following removal of the Boc group. To prevent removal of the Boc group, use of bulky Lewis acids, including triethylsilyl trifluoromethansulfonate (TESOTf) and tert-butyldiphenylsilyl trifluoromethansulfonate (TBDPSOTf) was attempted (entries 8 and 9). The yield was successfully improved while maintaining excellent diastereoselectivity. The best result was obtained using TBDPSOTf, which gave compound $\mathbf{6 c}$ in $65 \%$ yield (entry 9). Therefore, we could selectively access both diastereomers $\mathbf{6 c}$ and $\mathbf{1 1}$ by changing the reaction conditions.

Table 1. Investigation of [4+2] cycloaddition of the tetrasubstituted olefin
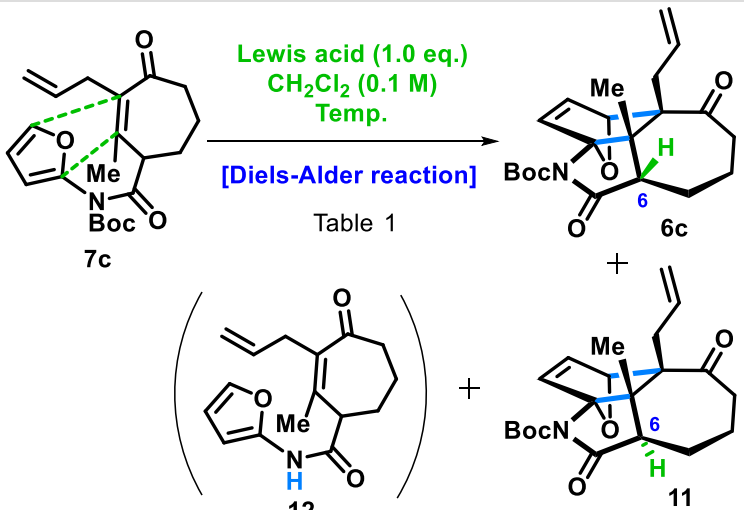

12

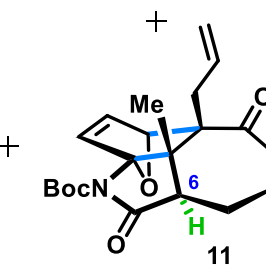

byproduct

\begin{tabular}{|c|c|c|c|c|c|}
\hline Entry & Lewis Acid & Temp. $\left({ }^{\circ} \mathrm{C}\right)$ & $6 c$ & 11 & 12 \\
\hline $1^{[a]}$ & none & 110 & $6 \%$ & $72 \%$ & - \\
\hline $2^{[b]}$ & $\mathrm{Mg}\left(\mathrm{ClO}_{4}\right)_{2}$ & 25 & - & - & $84 \%$ \\
\hline $3^{[c]}$ & $\mathrm{Yb}(\mathrm{OTf})_{3}$ & -78 to 40 & - & - & $52 \%$ \\
\hline $4^{[\mathrm{c}]}$ & $\mathrm{Ti}(\mathrm{O} / \mathrm{Pr})_{4}$ (0.5 eq.) & -78 to 25 & - & - & $51 \%$ \\
\hline $5^{[c]}$ & $\mathrm{Cu}(\mathrm{OTf})_{2}$ (2.0 eq.) & -78 to 0 & $10 \%$ & - & - \\
\hline $6^{[c]}$ & $\mathrm{BF}_{3} \cdot \mathrm{Et}_{2} \mathrm{O}$ & -78 to 0 & $18 \%$ & - & - \\
\hline 7 & TMSOTf & -78 & $27 \%$ & - & - \\
\hline 8 & TESOTf (0.2 eq.) & -78 & $45 \%$ & - & - \\
\hline
\end{tabular}

\section{TBDPSOTf (0.2 eq.) $\quad-78 \quad 65 \% \quad-\quad-$}

[a] PhMe (0.02 M) was used as a solvent instead of $\mathrm{CH}_{2} \mathrm{Cl}_{2}$. [b] $\mathrm{MeCN}$ $(0.05 \mathrm{M})$ was used as a solvent instead of $\mathrm{CH}_{2} \mathrm{Cl}_{2}$. [c] $0.05 \mathrm{M}$.

To explain the selectivity of this Diels-Alder reaction, we would propose two transition states $\mathbf{A}$ and $\mathbf{B}$, in which the Lewis acid coordinate to the oxygen atom of the $\alpha, \beta$ unsaturated ketone (Scheme 3). The transition state $\mathbf{A}$ for the desired diastereomer $\mathbf{6 c}$ would be more favorable than the transition state $\mathbf{B}$ for the diastereomer 11, presumably because of steric repulsion between the furan ring and the pseudo-axial hydrogen on C10. Because the retro-Diels-Alder reaction did not occur at the low reaction temperature in the presence of Lewis acid, the kinetic product $\mathbf{6 c}$ was obtained exclusively.

With compound $\mathbf{6 c}$ having the desired stereochemistry at C6 in hand, we turned our attention to the construction of the $\mathrm{E}$ ring of calyciphylline A-type alkaloids (Scheme 4). First, we attempted to reduce the amide on the C-ring to prevent undesired epimerization of $\mathrm{C} 6$ in the following transformation. Treatment of $\mathbf{6 c}$ with 1 equivalent of lithium triethylborohydride resulted in the selective reduction of the amide in the presence of the ketone, to afford the stable hemiaminal 13. Interestingly, treatment of hemiaminal 13 with $\mathrm{Et}_{3} \mathrm{SiH}$ and $\mathrm{InCl}_{3}$ in acetonitrile gave compound 14, in which the double bond was reduced. We assumed that this unanticipated reduction happened through reduction of the hemiaminal on the $\mathrm{C}$ ring, ring-opening of the oxabicyclo[2.2.1]heptane skeleton, and 1,4-reduction. Unfortunately, further transformation of the terminal olefin of compound 14 and formation of the E ring was problematic. Thus, we investigated reduction of the ketone of compound $\mathbf{6 c}$ through the enol triflate. Treatment of $\mathbf{6 c}$ with 1.2 equivalents of potassium bis(trimethylsilyl)amide (KHMDS) and Comins' reagent ${ }^{16}$ gave triflate $\mathbf{1 5}$ in $44 \%$ yield without epimerization. Triflate $\mathbf{1 5}$ was converted to triene $\mathbf{1 6}$ in $50 \%$ yield using $\mathrm{Pd}\left(\mathrm{PPh}_{3}\right)_{4}$ and $\mathrm{HCOOH}$. However, compound 16 was unstable and decomposed in a few hours.

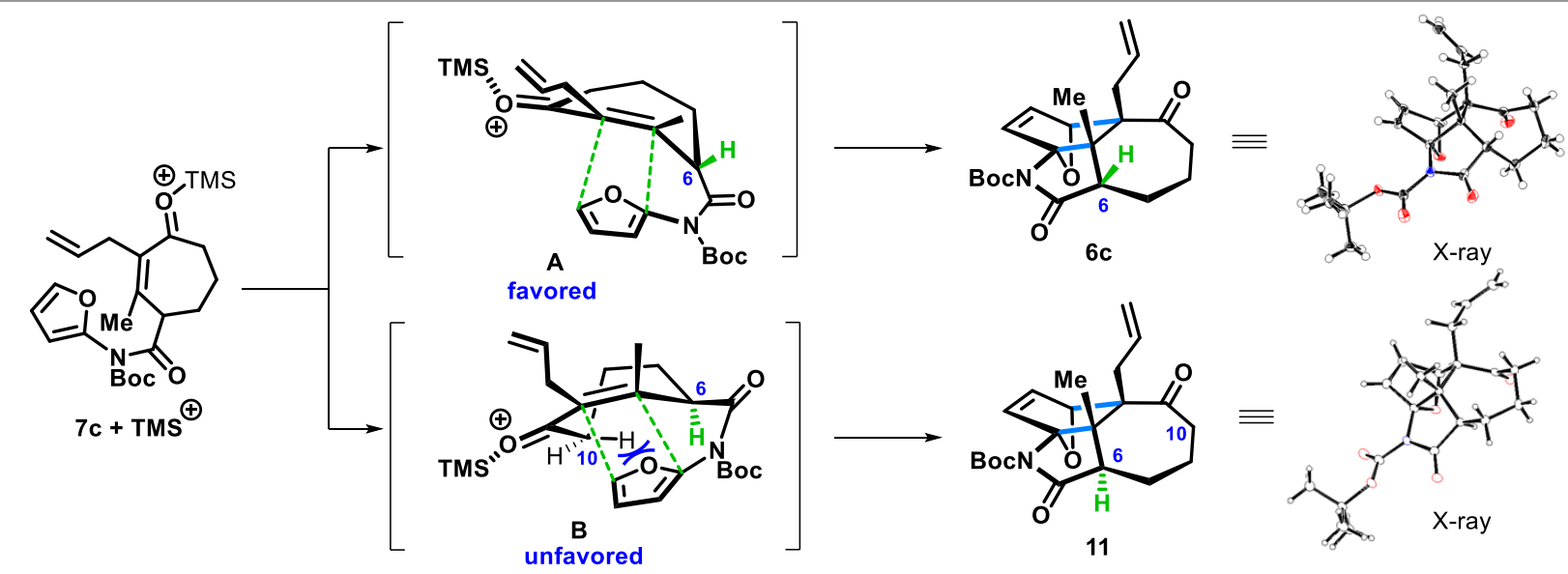

Scheme 3 Proposed transition states for the Diels-Alder Reaction of compound $7 \mathrm{c}$ in the presence of Lewis acid. (TMS ${ }^{+}$was used for simplification.) 

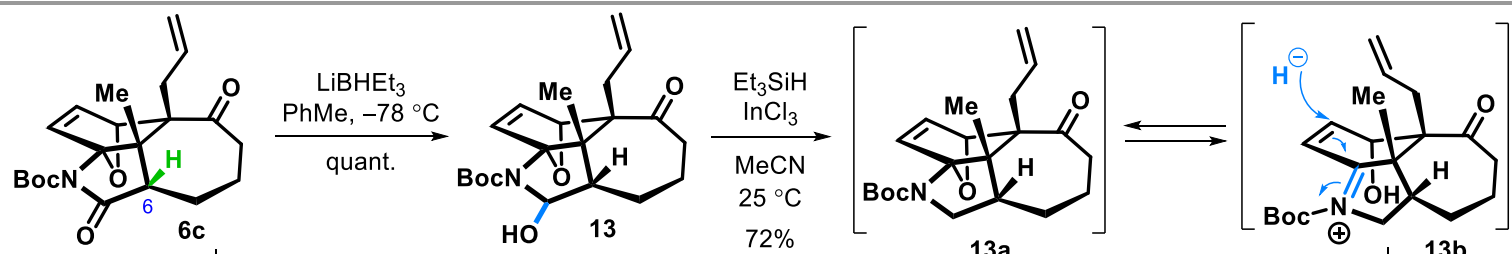

\begin{tabular}{c|c}
$\mathrm{KHMDS}(1.2 \mathrm{eq})$ & $\begin{array}{c}\text { Comins' reagent } \\
\text { THF, }-78^{\circ} \mathrm{C}\end{array}$
\end{tabular}

$13 a$
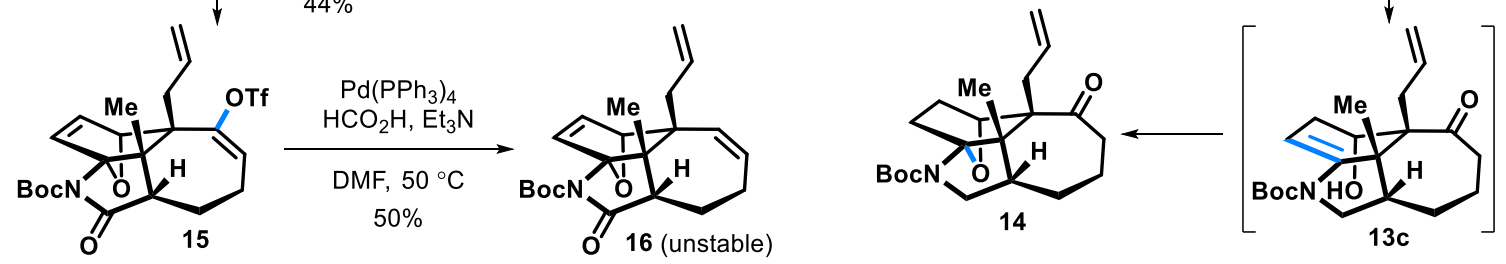

Scheme 4 Attempted derivatization of compound 6 .

Because the derivatization of compound $\mathbf{6 c}$ was difficult, presumably because of the skeletal strain, the thermodynamic Diels-Alder product 11, which had the undesired stereochemistry at C6, was investigated for formation of the $\mathrm{E}$ ring. After formation of enol triflate $\mathbf{1 7}$ from compound 11, reduction with $\mathrm{Pd}\left(\mathrm{PPh}_{3}\right)_{4}$ and $\mathrm{HCOOH}$ gave triene 18, which was sufficiently stable for storage and use in the next step (Scheme 5). The terminal olefin of compound $\mathbf{1 8}$ was oxidized to aldehyde 19 in $66 \%$ yield by anti-Markovnikov Wacker oxidation using $\mathrm{PdCl}_{2}\left(\mathrm{PhCN}_{2}, \mathrm{CuCl}_{2} \cdot \mathrm{H}_{2} \mathrm{O}\right.$, and $\mathrm{KNO}_{2} \cdot{ }^{17}$ Aldehyde 19 was treated with $\mathrm{NH}_{2} \mathrm{OH} \cdot \mathrm{HCl}$ and $\mathrm{NaOAc}$ to give oxime 20. After oxidation of compound $\mathbf{2 0}$ with $\mathrm{NaOCl}, \quad[3+2]$ cycloaddition smoothly proceeded in situ to afford the ACDE core $\mathbf{2 1}$ in $34 \%$ yield from triene 18. The relative stereochemistry of compound $\mathbf{2 1}$ was determined by NOE correlations between the protons on $\mathrm{C} 1$ and $\mathrm{C} 9, \mathrm{C} 9$ and $\mathrm{C} 6$, and C10 and C6 as shown in Scheme 5. Diimide reduction of compound $\mathbf{2 1}$ selectively reduced the double bond in the A ring in high yield (87\%).

In summary, we investigated the construction of the ACDE tetracyclic system of calyciphylline A-type alkaloids bearing two contiguous quaternary carbons. The synthesis of the ACD core was enabled in only a few steps through the intramolecular Diels-Alder reaction of a tetra-substituted olefin with furan. Then, an intramolecular [3+2] cycloaddition was effective in constructing the $\mathrm{E}$ ring. The final product $\mathbf{4}$ is a useful scaffold for the synthesis of calyciphylline A-type alkaloids, although it requires epimerization. Efforts to invert the stereochemistry at $\mathrm{C} 6$ and the construction of the B and F rings are ongoing in our laboratory.

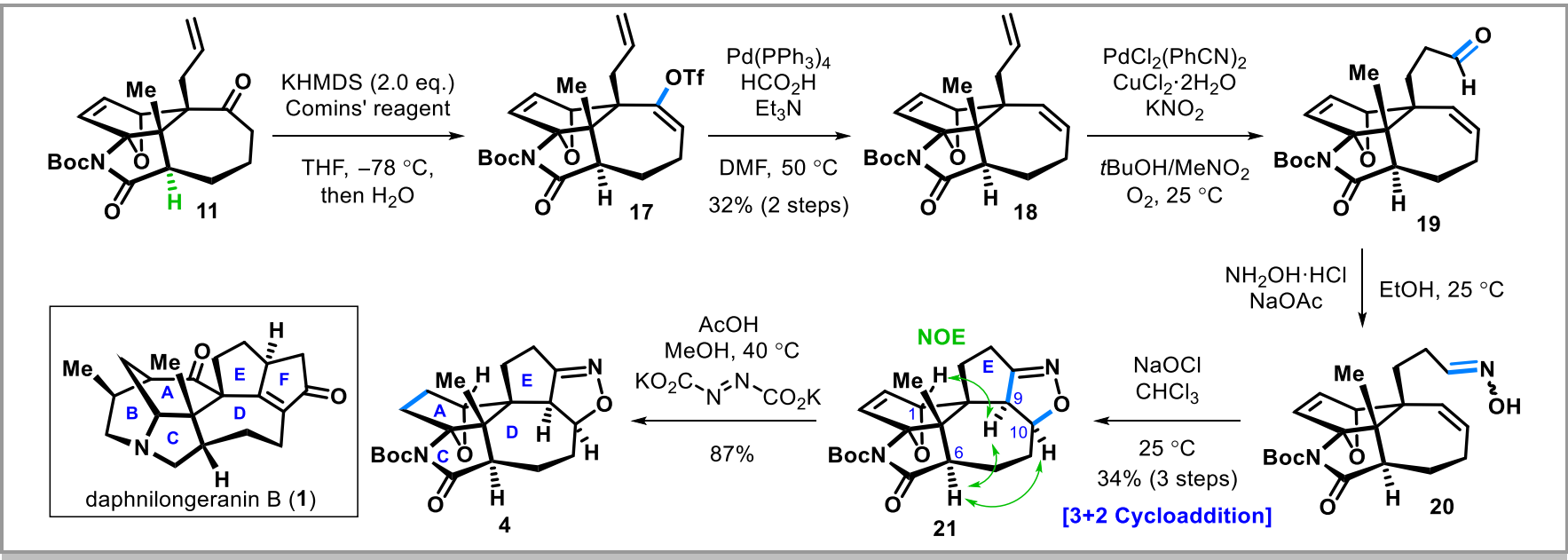

Scheme 5 Synthesis of the ACDE core 4 from compound 11 via [3+2] cycloaddition.

\section{Acknowledgments}

Victoria Muir, PhD, from Edanz Group (www.edanzediting.com/ac) edited a draft of this manuscript.

\section{Funding Information}

This work was supported by a Grant-in-Aid for Scientific Research (S) (JSPS KAKENHI no. 16H06384, Y.T.), a Grant-in-Aid for JSPS fellows (H.N.) and the JSPS KAKENHI (Grant No. JP17H05051, C.T.), and JSPS KAKENHI (Grant No. JP18H04407, C.T.) in the Middle Molecular Strategy.

\section{Supporting Information}

YES (this text will be updated with links prior to publication)

\section{Primary Data}

NO (this text will be deleted prior to publication)

\section{References and Notes}


(1) (d) Moria, H.; Kobayashi, J. Org. Lett. 2003, 5, 2895. (b) Zhang, $\mathrm{H}_{\text {; }}$ Yang, S.-P.; Fan, C.-Q.; Ding, J.; Yue, J.-M. J. Nat. Prod. 2006, 69, 553 (c) Mu, S.-Z.; Li, C.-S.; He, H.-P.; Di, Y.-T.; Wang, Y.; Wang, Y.-H.; Zhang, Z.; Lu, Y.; Zhang, L.; Hao, X.-J. J. Nat. Prod. 2007, 70, 1628. (d) Yang, S.-P.; Zhang, H.; Zhang, C.-R.; Chen, H.-D.; Yue, J.-M. J. Nat. Prod. 2006, 69, 79. (e) Takatsu, H.; Morita, H.; Shen, Y.-C.; Kobayashi, J. Tetrahedron 2004, 60, 6279.

(2) Kobayashi, J.; Kubota, T.; Nat. Prod. Rep. 2009, 26, 936.

(3) For reviews of the synthetic studies of Daphniphyllum alkaloids, see: (a) Kang, B.; Jakubec, P.; Dixon, D. J. Nat. Prod. Rep. 2014, 31, 550. (b) Chattopadhyay, A. K.; Hanessian, S. Chem. Rev. 2017, 117, 4104.

(4) (a) Sole, D.; Urbaneja, X.; Bonjoch, J. Org. Lett. 2005, 7, 5461. (b) Ikeda, S.; Shibuya, M.; Kanoh, N.; Iwabuchi, Y. Org. Lett. 2009, 11, 1833. (c) Sladojevich, F.; Michaelides, L. N.; Darses, B.; Ward, J. W.; Dixon, D. J. Org. Lett. 2011, 13, 5132. (d) Xu, C.; Liu, Z.; Wang, H.; Zhang, B.; Xiang, Z.; Hao, X.; Wang, D. Z. Org. Lett. 2011, 13, 1812. (e) Yao, Y.; Liang, G. Org. Lett. 2012, 14, 5499. (f) Xu, C.; Wang, L.; Hao, X.; Wang, D. Z. J. Org. Chem. 2012, 77, 6307. (g) Yang, M.; Wang, L.; He, Z. H.; Wang, S. H.; Zhang, S. Y.; Tu, Y. Q.; Zhang, F. M. Org. Lett. 2012, 14, 5114. (h) Darses, B.; Michaelides, L. N.; Sladojevich, F.; Ward, J. W.; Rzepa, P. R.; Dixon, D. J. Org. Lett. 2012, 14, 1684. (i) Wang, L.; Xu. C.; Chen, L.; Hao, X.; Wang, D. Z. Org. Lett. 2014, 16, 1076. (j) Xiong, X.; Li, Y.; Lu, Z.; Wan, M.; Deng, J.; Wu, S.; Shao, H.; Li, A. Chem. Commun. 2014, 50, 5294. (k) Ibrahim, A. A.; Golonka, A. N.; Lopez, A. M.; Stockdill, J. L. Org, Lett. 2014, 16, 1072. (I) Guo, J. J.; Li, L.; Cheng, B.; Xu, T.; Tao, C.; Yang, X.; Zhang, D.; Yan, G.; Zhai, H. Chem. Asian J. 2015, 10, 865. (m) Ma, D.; Cheng, H.; Huang, C.; Xu, L. Tetrahedron Lett. 2015, 56, 2492. (n) Stockdill, J. L.; Lopez, A. M.; Ibrahim, A. A. Tetrahedron Lett. 2015, 56, 3503. (o) Diaba, F.; Laporta, A. M.; Coussanes, G.; Fernandez, I.; Bonjoch, J. Tetrahedron 2015, 71, 3642. (p) Hayakawa, I.; Niida, K.; Kigoshi, H. Chem. Commun. 2015, 51, 11568. (q) Shao, H.; Bao, W.; Jing, Z. R.; Wang, Y. P.; Zhang, F. M; Wang, S. H.; Tu, Y. Q. Org. Lett. 2017, 19, 4648. (r) Coussanes, G.; Bonjoch, J. Org. Lett., 2017, 19, 878. (s) Lopez, A. M.; Ibrahim, A. A.; Rosenhauer, G. J.; Sirinimal, H. S.; Stockdill, J. L. Org. Lett. 2018, 20, 2216. (t) Sasano, Y.; Koyama, J.; Yoshikawa, K.; Kanoh, N.;
Kwon, E.; Iwabuchi, Y. Org. Lett. 2018, 20, 3053. (u) Mo, X. F.; Li, Y. F.; Sun, M. H.; Dong, Q. Y.; Xie, Q. X.; Tang, P.; Xue, F.; Qin, Y. Tetrahedron Lett. 2018, 59, 1999. (w) Kitabayashi, Y.; Fukuyama, T.; Yokoshima, S. Org. Biomol. Chem. 2018, 16, 3556.

(5) Additionally, compounds closely related to the calyciphylline Atype subfamily, including daphmanidine E, calyciphylline $\mathrm{N}$, and daphenylline have been recently synthesized: (a) Weiss, M. E.; Carreira, E. M. Angew. Chem., Int. Ed. 2011, 50, 11501. (b) Shvartsbart, A.; Smith, A. B. J. Am. Chem. Soc. 2014, 136, 870. (c) Lu, Z.; Deng, Y.; Li, A. Nat. Chem. 2013, 5, 679. (d) Yamada, R.; Adachi, Y.; Yokoshima, S.; Fukuyama, T. Angew. Chem. Int. Ed. 2016, 55, 6067.

(6) Li, J.; Zhang, W.; Chen, Y.; Li, A. J. Am. Chem. Soc. 2017, 139, 14893.

(7) Chen, X.; Zhang, H. J.; Yang, X.; Lv, H.; Shao, X.; Tao, C.; Wang, H.; Cheng, B.; Li, Y.; Guo, J.; Zhang, J.; Zhai, H. Angew. Chem. Int. Ed. 2018, 57, 947.

(8) Chen, Y.; Zhang, W.; Lu, R.; Li, J.; Li, A. Angew. Chem. Int. Ed. 2018, $57,952$.

(9) Shi, H.; Michaelides, I.N.; Darses, B.; Jakubec, P.; Nguyen, Q. N. N.; Paton, R. S.; Dixon, D. J. J. Am. Chem. Soc. 2017, 139, 17755.

(10) Zhang, W.; Ding, M.; Li, J.; Guo, Z.; Lu, M.; Chen, Y.; Liu, L.; Shen, YH.; Li, A. J. Am. Chem. Soc. 2018, 140, 4227.

(11) Nakamura, H.; Kawakami, M.; Tsukano, C.; Takemoto, Y. Chem. Eur J. 2019, 25, 8701

(12) Padwa, A.; Lynch, S. M.; Mejia-Oneto, J. M.; Zhang, H. J. Org. Chem. 2005, 70, 2206.

(13) Michaelides, I. N.; Darses, B.; Dixon, D. J. Org. Lett. 2011, 13, 664.

(14) Brodney, M. A.; Cole, M. L.; Freemont, J. A.; Kyi, S.; Junk, P. C.; Padwa, A.; Riches, A. G.; Ryan, J. H. Tetrahedron Lett. 2007, 48, 1939.

(15) We observed that compound $\mathbf{6 c}$ was converted to compound $\mathbf{1 1}$ in refluxing toluene through retro Diels-Alder reaction. Also see Supporting Information.

(16) Comins, D. L.; Dehghani, A. Tetrahedron Lett. 1992, 33, 6299.

(17) Wickens, Z. K.; Morandi, B.; Grubbs, R. H. Angew. Chem. Int. Ed. 2013, 52, 11257 